\title{
Morphology of Lithothamnion japonicum (Hapalidiaceae, Rhodophyta): A New Record of Coralline Species from Korea
}

\author{
So Young Jeong, Boo Yeon Won and Tae Oh Cho* \\ Department of Life Science, Chosun University, Gwangju 61452, Republic of Korea
}

\begin{abstract}
The morphology, anatomy and reproduction (tetra/bisporic and male) of Lithothamnion japonicum Foslie was studied, using holotype material and materials collected from Korea. Lithothamnion japonicum is characterized based on the presence of encrusting, warty to fruticose thallus, branched or unbranched short and cylindrical protuberances, conical shaped spermatangial conceptacles, branched (dendroid) spermatangial systems formed on floor, walls, and roof of conceptacle chamber, cylindrical shaped spermatangial conceptacle canal, 9-10 cell layered spermatangial conceptacle roof, raised tetra/bisporangial conceptacles without rims, flattened tetra/ bisporangial conceptacle pore plate, 16-50 pores on each pore plate, 6-8 rosette cells surrounded by each pore, pore canal lining filaments composed of tetra/bisporangial conceptacle roof, and buried senescent tetra/bisporangial conceptacles completely infilled with relatively large and irregularly arranged calcified sterile cells. In this study, we report a new record of Lithothamnion japonicum from Korean coasts.
\end{abstract}

Keywords : Hapalidiaceae, Korea, Lithothamnion japonicum, morphology, taxonomy

\section{INTRODUCTION}

Coralline algae are the most distinctive and recognizable benthic marine plants and commonly constitute a dominant component of intertidal and subtidal communites (Woelkerling 1988). Despite their ubiquity, however, they are not easily recognised and have been a relatively poorly studied group of marine organisms (Maneveldt et al. 2008). In Korea, corallines are common both in intertidal and subtidal habitats, but they are poorly documented in the flora of Korea.

Lithothamnion Heydrich (1897) was proposed as conservation of the latter homonym for Lithothamnium Philippi (1837) (Woelkerling 1985). It was based on L. muelleri Lenormand ex Rosanoff collected from Western port bay, Victoria, Australia (Wilks and Woelkerling 1995: 555). Currently, 83 spe-

* Corresponding author: Tae Oh Cho, Tel. 062-230-7161, Fax.062-230-7161,E-mail. tocho@chosun.ac.kr cies of Lithothamnion have been recognized mostly based on morphological analyses (Guiry and Guiry 2018). Of them, Lithothamnion japonicum Foslie is recorded as endemic species in the North-west Pacific. Lithothamnion japonicum was originally reported with simple description from Muroran, Iburi Subprefecture, Hokkaido in Japan (Foslie 1900). It was characterized by a knotty thallus with subdichotomously branched protuberances, convex but very little prominent tetra/bisporangial conceptacles, tetra/bisporangial conceptacle roof intersected with a small number of delicate muciferous canals, and buried senescent tetra/bisporangial conceptacles (Foslie 1900). Although L. japonicum is recorded in the checklists of the flora of Japan and China (e.g. Okamura 1936; Yoshida et al. 1990; Yoshida 1998; Liu 2008; Zeng 2009; Xia 2013; Yoshida et al. 2015), it has not been reported in Korea until now.

We have recently collected some unidentified samples resembled with L. japonicum from the coastline of Korea. We 
observed their morphology and anatomy in detail and compared them with the holotypes of L. japonicum and L. fretense which was already synonymized with L. japonicum. In this study, we confirm the validity of L. japonicum, represent its detailed anatomical structures according in modern context, and extend its distribution to Korea.

\section{MATERIALS AND METHODS}

\section{Samples}

Fresh samples of Lithothamnion japonicum were collected from intertidal zones of Sokcho, Pohang, Oeyon-do, Heuksan-do, and Hong-do in Korea during 2014-2016 and compared with their type materials. Our samples were removed from the bedrock, small boulders, and mollusks using a chisel and hammer and were preserved in silica gel for anatomical morphology and molecular investigation. In addition, the holotype materials of L. japonicum and L. fretense were borrowed from the Herbarium, Museum of Natural History and Archaeology, Norwegian University of Science and Technology, Trondheim, Norway (TRH).

\section{Morphology}

For light microscopy (LM), the dried samples in silica gel were completely decalcified in $0.6 \mathrm{M}$ nitric acid for a minimum of 30 min until gas bubbles cease forming, rinsed with distilled water, and then stained using a 3:7 mixture of $1 \%$ aqueous aniline blue and glycerin solution (1:9 glycerol : $80 \%$ ethanol) for more than $30 \mathrm{~min}$. Sections of thallus (5$20 \mu \mathrm{m}$ thickness) were prepared using an embedding matrix (O.C.T.; CellPath, Ltd., Newtown, Wales, UK) and a freezing microtome (Shandon Cryotome FSE; Thermo Shandon, Ltd., Loughborough, UK) and the sections were stained using a 3 : 7 mixture of $1 \%$ aqueous aniline blue and glycerin solution and then treated with Mayer's hematoxylin (Electron Microscopy Sciences, PA, USA). Photomicrographs were taken using an Olympus microscope (BX51TRF; Olympus, Tokyo, Japan) and an Olympus DP71 camera.

For scanning electron microscopy (SEM), the dried samples were fractured by hammer and chisel, mounted on aluminum stubs using double-sided adhesive carbon tape (Nisshin EM Co., Ltd., Tokyo, Japan), and coated with gold for $10 \mathrm{~min}$ using digital ion coater (SPR-20, COXEM Co., Ltd., Daejeon, Korea). The samples were examined using a COXEM EM-30 PLUS + scanning electron microscope (Mini SEM; COXEM Co., Ltd, Korea) with an accelerating voltage of $15 \mathrm{kV}$.

Thallus anatomical terminology follows Chamberlain (1990). Morphological (growth forms) terminology follows Woelkerling et al. (1993). In cell measurement, length denotes the distance between primary pit connections, and diameter the maximum width of the cell lumen at right angles to this. Conceptacle measurements follow Adey and Adey (1973).

\section{RESULTS}

Lithothamnion japonicum Foslie, 1900 돌기쩍(신칭) (Figs. 1-5)

Heterotypic synonym: Lithothamnion fretense Foslie, 1907. Holotype: TRH C16-3267; Miyabe No. 7; slides 391, 1158 (Woelkerling et al. 2005: 456).

Type locality: Muroran, Iburi Subprefecture, Pacific Coast, Hokkaido, Japan (Yoshida 1998; Woelkerling et al. 2005: 456).

Material examined: Holotype of Lithothamnion japonicum, TRH C16-3267 (Muroran, Iburi Subprefecture, Hokkaido, Japan, collected by Miyabe, 21.iii.1897, attached on the holdfasts of Laminaria, tetrasporophyte); holotype of $L$. fretense, TRH C15-3228 (Kaifuura, Echigo Province, Japan, collected by Yendo, no date, 1899, no habitat data, tetrasporophyte); CUK12890 (Daepo harbor, Daepo-dong, Sokchosi, Gangwon-do, Korea, collected by S.Y.J and T.O.C, 31. vii.2014, epilithic on rock in intertidal zone, tetrasporophyte); CUK13407 (Oeyondo-ri, Ocheon-myeon, Boryeong-si, Chungcheongnam-do, Korea, collected by S.Y.J and T.O.C, 20.i.2015, epizoic on limpet in intertidal zone, tetrasporophyte); CUK13415, CUK13417, CUK13428 (Gorageum, Oeyondo-ri, Ocheon-myeon, Boryeong-si, Chuncheongnamdo, Korea, collected by S.Y.J and T.O.C, 19.i.2015, epilithic on rocks in intertidal zone, male and tetrasporophyte); CUK 15495 (Seokbong 2-ri, Guryongpo-eup, Nam-gu, Pohang-si, Gyeongsangbuk-do, Korea, collected by S.Y.J and T.O.C, 26.xii.2015, epizoic on gastropods in intertidal zone, tetra- 


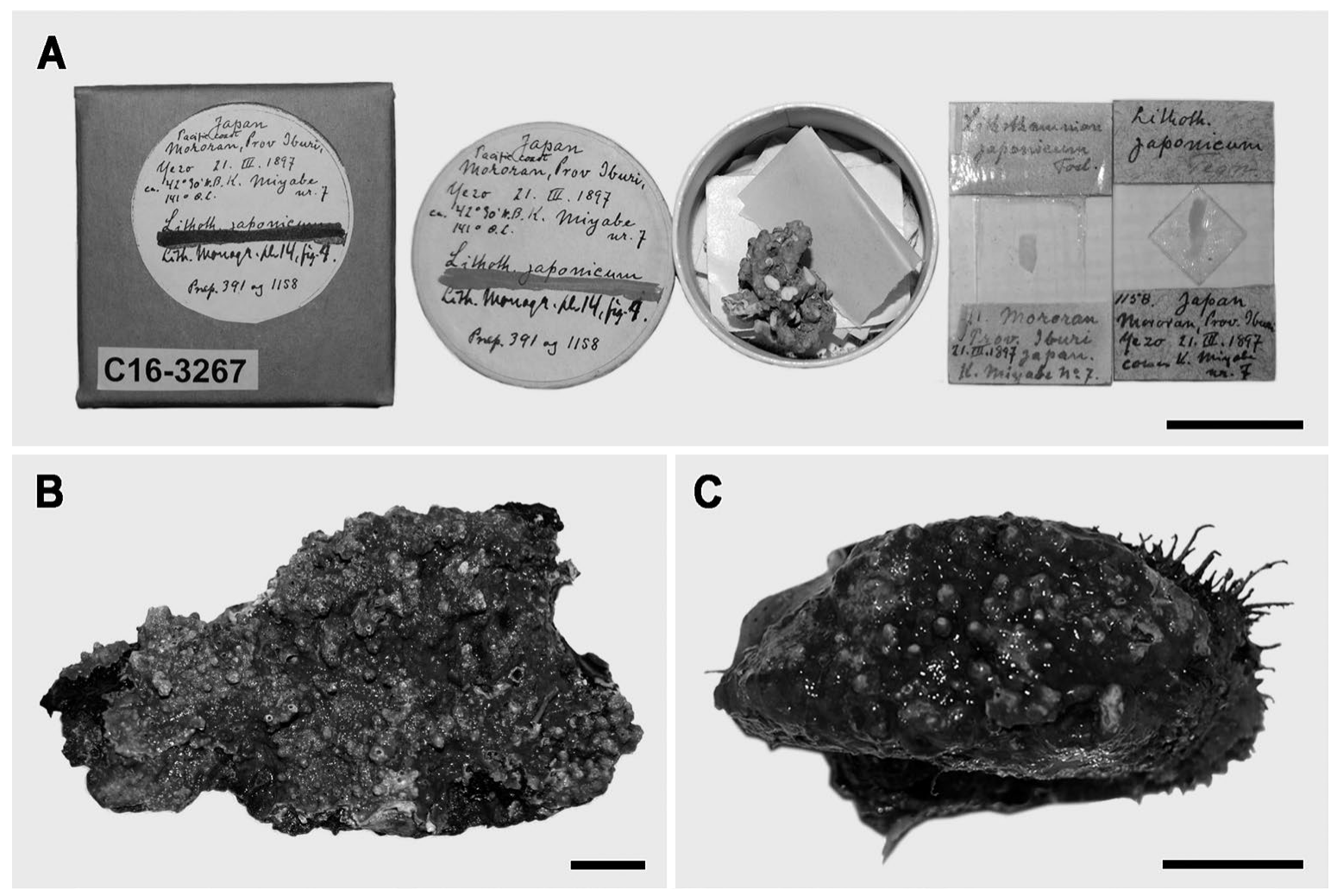

Fig. 1. Diversity growth forms of Lithothamnion japonicum. A. Holotype specimen of Lithothamnion japonicum (TRH C16-3267); B. Epilithic specimens of L. japonicum (CUK13415) on the rock; C. Epizoic specimens of L. japonicum (CUK13407) on shell. Scale bars: A-C= $1 \mathrm{~cm}$.

sporophyte); CUK17325 (Sa-ri, Heuksan-myeon, Shinangun, Jeollanam-do, Korea, collected by S.Y.J and T.O.C, 20.v.2016, epilithic on rocks in intertidal zone, male); CUK 17349, CUK 17365 (Hongdo harbor, Hongdo-ri, Heuksanmyeon, Shinan-gun, Jeollanam-do, Korea, collected by S.Y.J and T.O.C, 21.v.2016, epilithic on rocks in intertidal zone, tetrasporophyte), NIBRD0000003220 (deposited in the National Institute of Biological Resources).

Vegetative morphology: Plants are dark red in color, encrusting, firmly attached to substrate (sometimes easy to detach) with or without conspicuous white edges, matt textured, warty to knobby (Figs. 1A-C, 5A). Protuberances are short, cylindrical, branched or unbranched (simple), 5-7 mm long and 6-60 $\mathrm{mm}$ wide at the distal end. Surface cells have thickened calcareous ridges that surround central concavities (Fig. 2A). Thalli are pseudoparenchymatous, monomerous, and dorsiventrally organized (Fig. 2B). In protuberances, they are composed of a central core of filaments and a peripheral region where distal portions of core filaments or their deriva- tives curve outwards towards the thallus surface (Fig. 5B). Haustoria are absent. The crustose portion of the thallus is $147-716 \mu \mathrm{m}$ thick and composed of medulla and cortex. The medulla is plumose (non-coaxial), 21-91 $\mu \mathrm{m}$ thick, and comprised of approximately 5-12 cell layers, which is usually less than $8-39 \%$ of the mature thallus thickness. Cells of the medullary filament are rectangular to elongated with rounded corners, 2-3 times as long as wide, 6-27 $\mu \mathrm{m}$ in length, and 3-7 $\mu \mathrm{m}$ in diameter (Fig. 2C). The ventrally situated medullary filaments curve downwards toward the substratum and terminate into more- or less triangular-shaped cells (Fig. 2C). The medullary cells are composed of filaments running more or less parallel to the thallus surface (Fig. 2D). Medullary filaments curve toward the thallus surface to form a zoned cortex (cortical region). The cortex is $70-624 \mu \mathrm{m}$ and comprising $61-92 \%$ of the thallus thickness. Cells of the cortical filaments are square to oblong, 2-13 $\mu \mathrm{m}$ in length, and 4-6 $\mu \mathrm{m}$ in diameter (Figs. 2E and 5C). Epithallial cells are arranged in a single layer, flattened and flared, 1-3 $\mu \mathrm{m}$ 


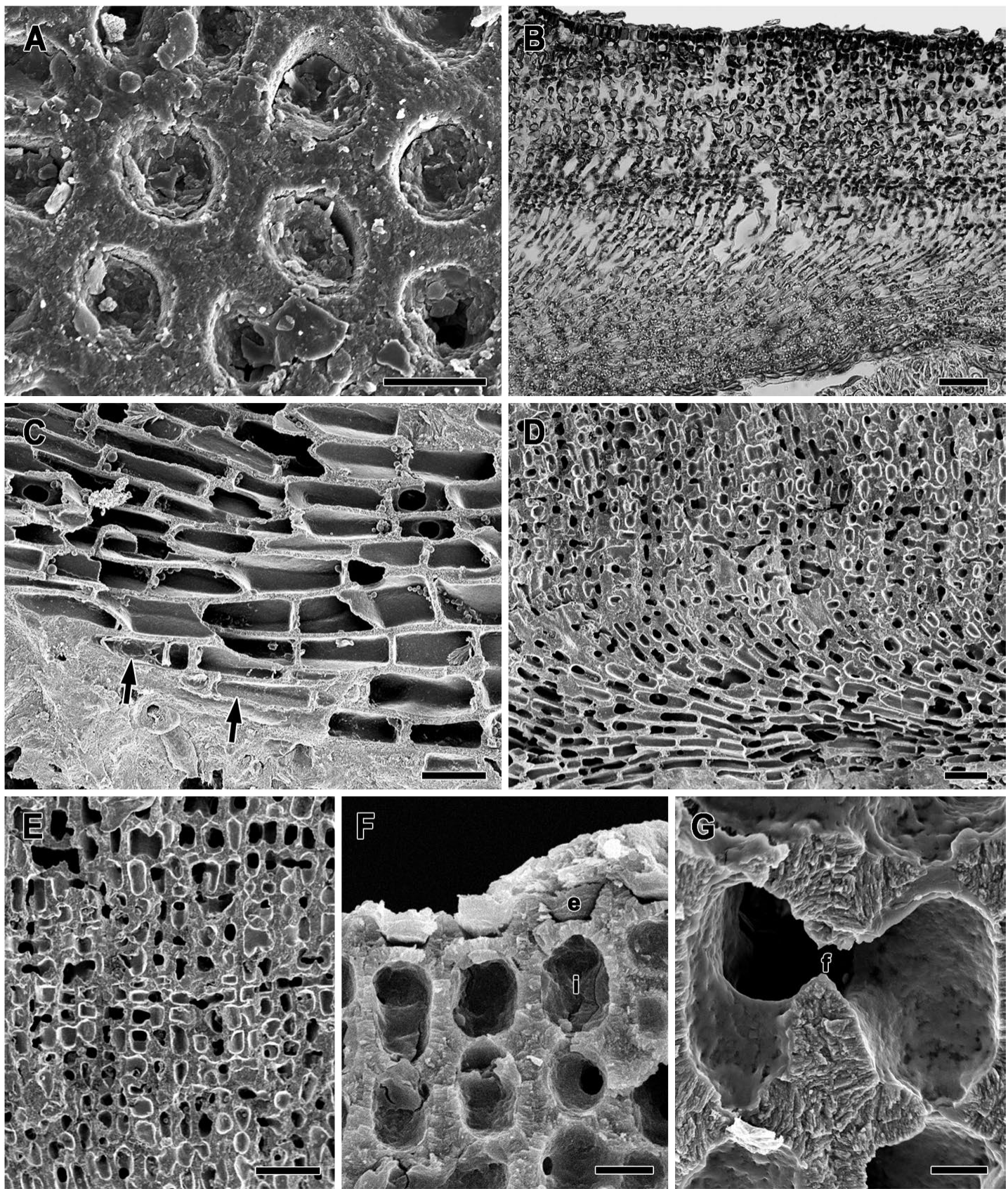

Fig. 2. Vegetative structures of Lithothamnion japonicum (TRH C16-3267, CUK13407, CUK13415, and CUK13428). A. Surface view of thickened calcareous ridges surrounding the central concavities; B. Vertical section view of thallus; C. Vertical section view of ventrally situated medullary filaments showing their termination in cells with angular end walls (arrows); D. Vertical section view of medullary systems showing monomerous construction; E. Vertical section view of cortical filaments; F. Vertical section view of outer cortical filaments showing flared epithallial cells (e) and subepithallial initials (i) that are as long as or longer than the subtending them; G. Vertical section view of cortical region showing cell fusion (f) connecting the adjacent filament. Scale bars: $\mathrm{A}, \mathrm{F}=5 \mu \mathrm{m} ; \mathrm{B}, \mathrm{D}, \mathrm{E}=$ $20 \mu \mathrm{m} ; \mathrm{C}=10 \mu \mathrm{m} ; \mathrm{G}=2 \mu \mathrm{m}$.

in length, and 4-5 $\mu \mathrm{m}$ in diameter (Figs. 2F and 5D). Subepithallial initials are rectangular with rounded corner, as long as or longer than the cells immediately subtending them,
2-9 $\mu \mathrm{m}$ in length, and 3-7 $\mu \mathrm{m}$ in diameter (Figs. $2 \mathrm{~F}$ and 5D). Fusions between the cells of contiguous medullary and cortical filaments are abundant and frequently occupy most of 

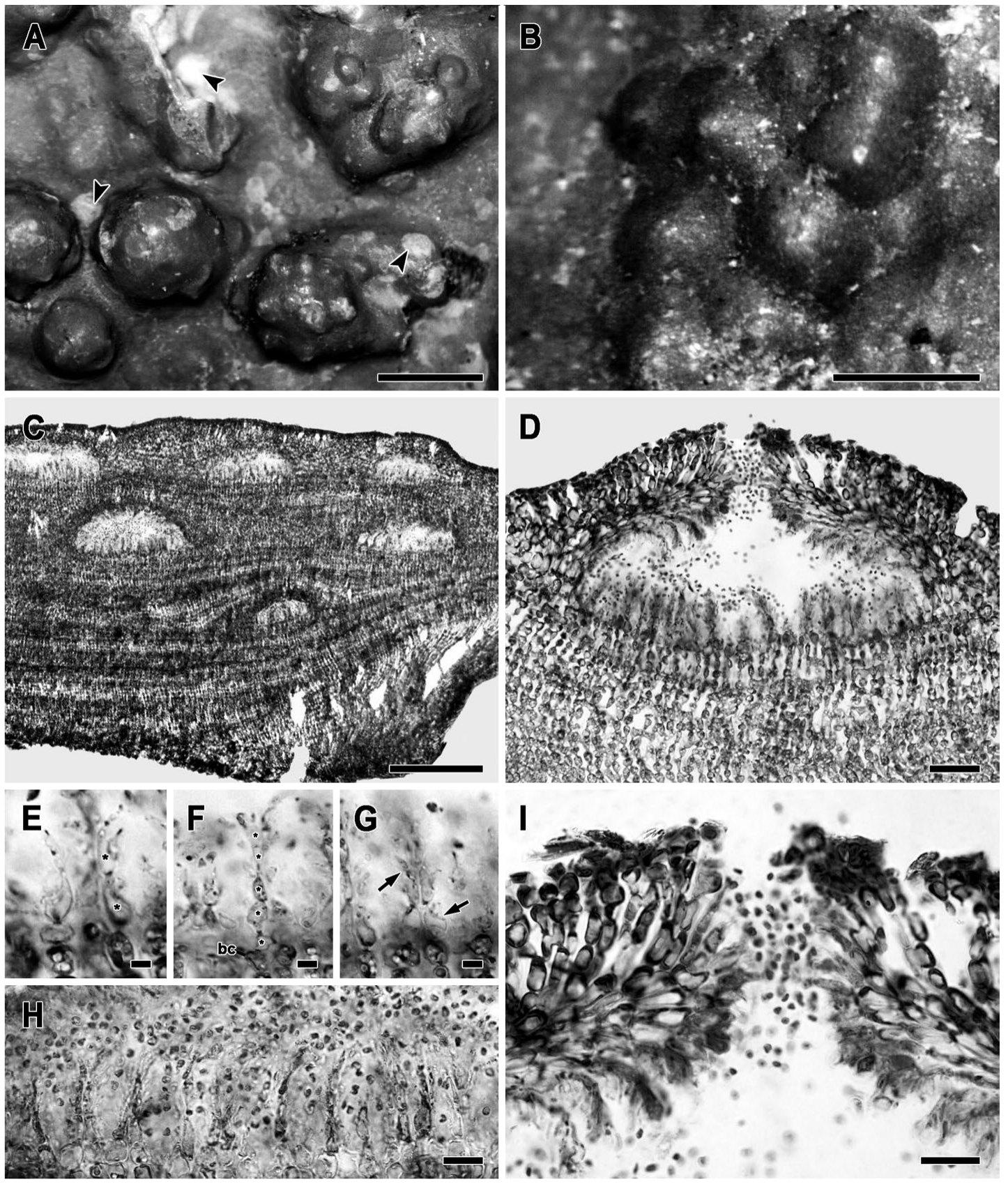

Fig. 3. Male structures of Lithothamnion japonicum (CUK13428 and CUK17325). A. Surface view of immature male conceptacles shedding thin white cap (arrowhead); B. Surface view of matured male conceptacles; C. Vertical section view showing several buried male conceptacles; D. Vertical section view of mature male conceptacle showing branched spermatangial filaments; E-G. Development of spermatangial filament composed of spermatangial mother cells (*, arrows) on basal cell (bc); H. Detailed view of branched spermatangial filaments; I. Vertical section view of male conceptacle roof. Scale bars: $A=1 \mathrm{~mm} ; \mathrm{B}=500 \mu \mathrm{m} ; \mathrm{C}=100 \mu \mathrm{m} ; \mathrm{D}=20 \mu \mathrm{m} ; \mathrm{E}-\mathrm{G}=2 \mu \mathrm{m}$; $\mathrm{H}=5 \mu \mathrm{m} ; \mathrm{I}=10 \mu \mathrm{m}$.

the walls of adjoining cells (Fig. 2G). Secondary pit connections and trichocytes have not been observed.

Reproductive structures: Gametangial thalli are dioecious. In male plants, the spermatangial conceptacles are initially more or less flush with the thallus surface, shed a thin white cap (Fig. 3A), raised to conical shape, occur mainly on the tips of protuberances, and 46-61 $\mu \mathrm{m}$ in thickness above the thallus surface without rims (Fig. 3A and B). Spermatangial 

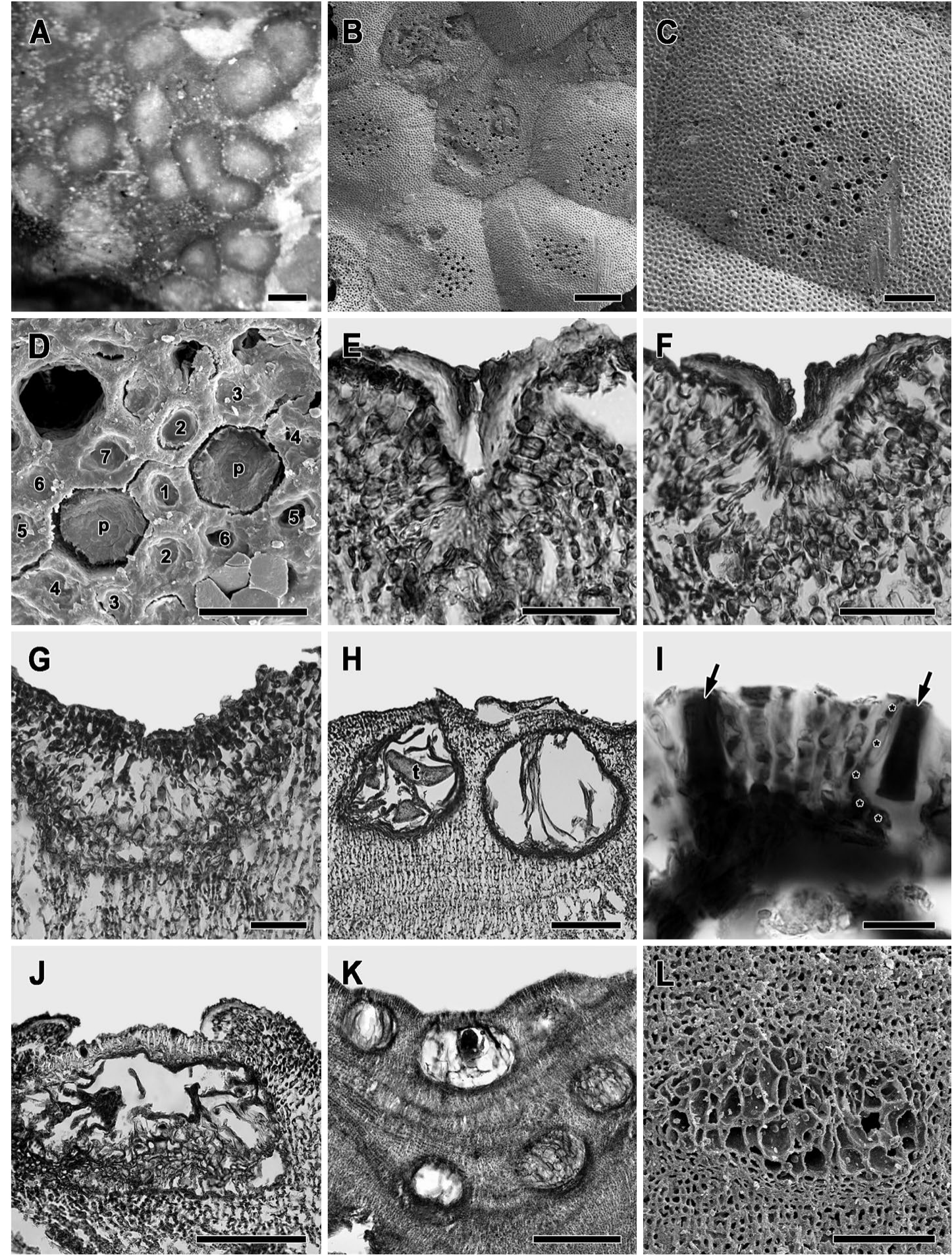

Fig. 4. Tetra/bisporangial structures of Lithothamnion japonicum (TRH C16-3267, CUK12890, CUK13407, CUK13415, and CUK13417). A. Surface view of tetra/bisporangial conceptacles; B. Surface view of tetra/bisporangial conceptacles showing a raised multiporate pore plate; C. Detailed view of pore plate comprised of a number of pores; D. Surface view of pores (p) bordered by a rosette of 6-7 cells (labelled 1 to 6-7); E-G. Developmental series of tetra/bisporangial conceptacle formation; H. Vertical section view of tetra/bisporangial conceptacles showing tetrasporangia ( $\mathrm{t}$ ); I. Detailed view of apical plugs (arrows) and pore canal lining cells (asterisks); J. Vertical section view of old tetra/bisporangial conceptacle showing peripheral filaments enclosing the chamber; K. Vertical section view of several buried tetra/bisporangial conceptacle chambers; L. Vertical section view of buried tetra/bisporangial conceptacle chamber infilled with calcified sterile cells. Scale bars: $A=200 \mu \mathrm{m} ; \mathrm{B}, \mathrm{K}, \mathrm{L}=100 \mu \mathrm{m} ; \mathrm{C}, \mathrm{H}=50 \mu \mathrm{m} ; \mathrm{D}, \mathrm{I}=10 \mu \mathrm{m} ; \mathrm{E}-\mathrm{G}, \mathrm{J}=25 \mu \mathrm{m}$. 


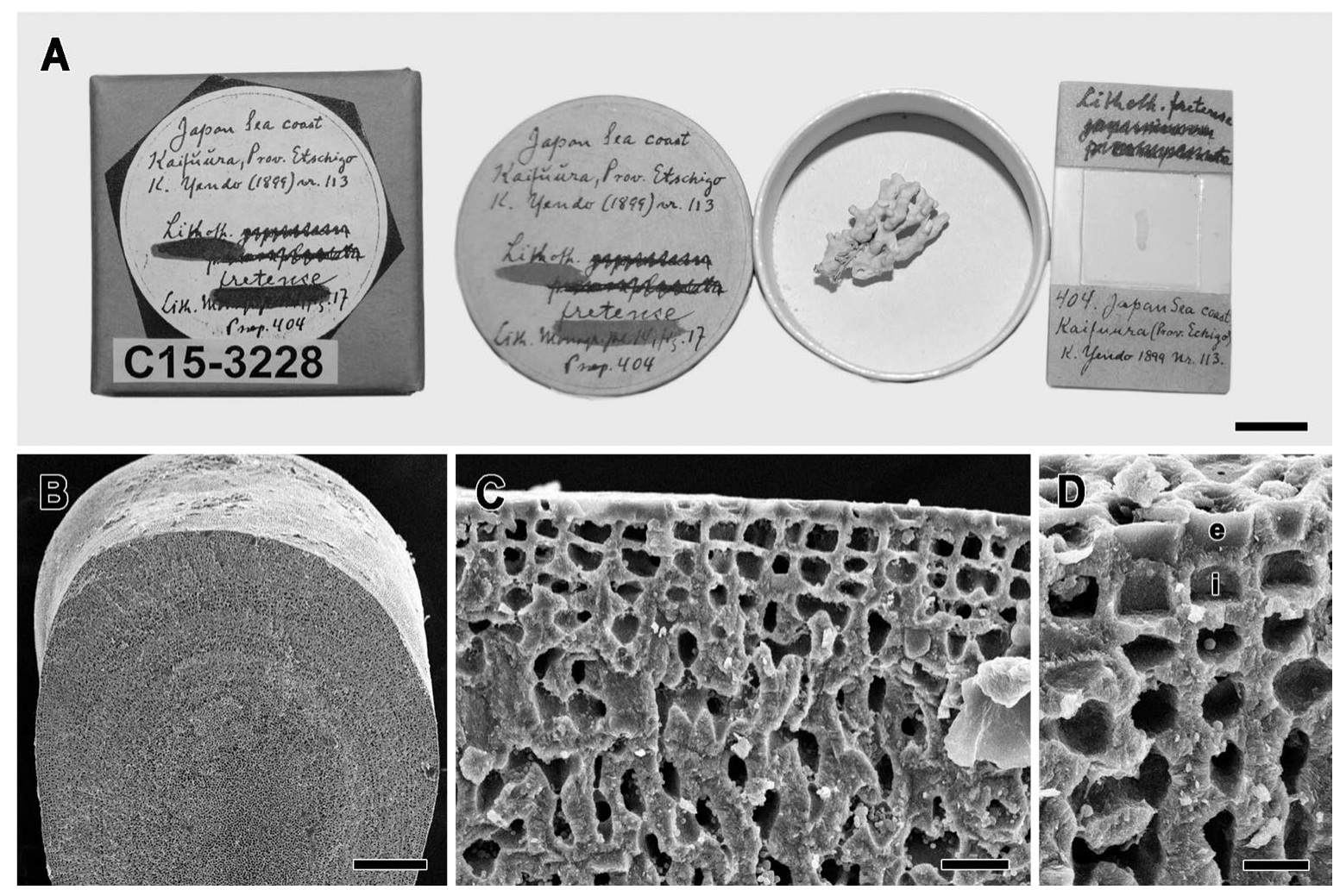

Fig. 5. Vegetative structures of Lithothamnion fretense (TRH C15-3228). A. Holotype specimen of Lithothamnion fretense (TRH C15-3228); B. Vertical section view of protuberance showing central core of filaments; C. Vertical section view of cortical filaments; D. Vertical section view of outer cortical filaments showing flared epithallial cells (e) and subepithallial initials (i) that are as long as or longer than the subtending them. Scale bars: $A=1 \mathrm{~cm} ; \mathrm{B}=200 \mu \mathrm{m} ; \mathrm{C}=10 \mu \mathrm{m} ; \mathrm{D}=5 \mu \mathrm{m}$.

conceptacles are $308-452 \mu \mathrm{m}$ in external diameter. Conceptacle chambers are hemispherical, 83-145 $\mu \mathrm{m}$ in diameter, and $26-59 \mu \mathrm{m}$ in height (Fig. $3 \mathrm{C}$ and D). Spermatangial conceptacle primordia develop from small group of subepithallial initials of the dorsal region of the thallus. Protective cells above spermatangial initials are not observed in young male conceptacles. Branched (dendroid) spermatangial systems develop across the floor, walls, and roof in mature conceptacles (Fig. 3D). During the early developmental stages of conceptacle, a group of meristematic cells differentiates into spermatangial initials. Spermatangial initials cut off into two to five spermatangial mother cells that then form a dense, deeply stained layer constituting the fertile area of the conceptacle (Fig. 3E-G). Spermatangial mother cells are elongated and divided to form dendroid branching systems and cut off the spermatangia $(2 \times 2 \mu \mathrm{m}$ in size) (Fig. $3 \mathrm{H})$. The roofs of conceptacles are 27-36 $\mu \mathrm{m}$ thick and formed from peripheral filaments that arch over and enclose the chamber. Pore canals of conceptacles are cylindrical, 17-20 $\mu \mathrm{m}$ in di- ameter, and 35-40 $\mu \mathrm{m}$ in length (Fig. 3I). The roof filaments are composed of 9-10 cell layers and their terminal initials are developed into papillae along the pore canal (Fig. 3I). Papillae project into the pore canal and are orientated more or less parallel to perpendicular to the conceptacle roof surface (Fig. 3I). Senescent male conceptacles are buried in the tissue (Fig. 3C). Female plants have not been observed.

In tetra/bisporangial plants, conceptacles are multiporate, raised to low-domed to polygonal shape, crowded, not confluent, $208-407 \mu \mathrm{m}$ in external diameter, and $28-70 \mu \mathrm{m}$ in thickness above the surrounding thallus surface without rims (Fig. 4A-C). Pore plates are flattened, approximately 152$225 \mu \mathrm{m}$ in diameter, and composed of 16-50 pores (Fig. 4C). The pores are usually crowded in the central part on the pore plates (Fig. 4C), surrounded by 6-8 rosette cells, and not protruded or sunken (Fig. 4D). Conceptacle primordia develop from small group of subepithallial initials within the dorsal region of the thallus (Fig. 4E-G). Tetra/bisporangial chambers are rounded to elliptical, $114-340 \mu \mathrm{m}$ in diameter, and 
$85-173 \mu \mathrm{m}$ in height (Fig. $4 \mathrm{H})$. Tetrasporangia are zonately divided, scattered across the chamber floor, 55-100 $\mu \mathrm{m}$ in height, and 12-20 $\mu \mathrm{m}$ in diameter. Bisporangia were not detected. The roofs of tetra/bisporangial conceptacles are 16-32 $\mu \mathrm{m}$ in thickness and composed of pore canals, pore canal lining filaments, and roof filaments. The pore canals of conceptacles are 4-7 $\mu \mathrm{m}$ in diameter and blocked by apical plugs (Fig. 4I). The filaments lining the pore canal are composed of 4-6 cells and are similar to roof filaments in the shape and size (Fig. 4I). Senescent tetra/bisporangial conceptacles are buried and completely infilled with relatively large and irregularly arranged calcified sterile cells (Fig. 4J and K).

Habitat and phenology: Plants are collected from high to low intertidal zone in sheltered to wave-exposed area of the reef. They occur in pink to rose-colored patches. Holotype material of L. japonicum was epiphytic on the holdfasts of Laminaria. Most plants grow on gastropod, limpet, or rock. Male plants are collected in January and May. Tetra/bisporangial plants are collected in January, March, May, July, and December.

World distribution: Korea, China, and Japan.

Deposition: Collected specimens are deposited in the National Institute Biological Resources (NIBR) and herbarium of Chosun University (CUK), Korea.

Identifier: Tae Oh Cho and So Young Jeong.

\section{DISCUSSION}

Within the genus Lithothamnion, most species are poorly known, and in the absence of a world monograph, species delimitation is attended by many uncertainties. The original diagnostic characters of many coralline species have been based on only a few anatomical features of slight or doubtful taxonomic relevance (Aguirre and Braga 2005). Because of the lack of reliable definitions, available names in the literature have rarely been used by subsequent authors (Bassi et al. 2007). Recently, however, reassessments of the original collections and freshly material have been carried out in the context of modern taxonomic understanding (e.g. Basso and Rodondi 2006; Tâmega et al. 2014; Peña et al. 2018).

Lithothamnion japonicum is characterized such as encrusting, warty to fruticose thallus, branched or unbranched short and cylindrical protuberances, conical shaped spermatangial conceptacles, branched (dendroid) spermatangial systems formed on floor, walls, and roof of conceptacle chamber, cylindrical shaped spermatangial conceptacle canal, 9-10 cell layered spermatangial conceptacle roof, raised tetra/bisporangial conceptacles without rims, flattened tetra/bisporangial conceptacle pore plate, $16-50$ pores on each pore plate, 6-8 rosette cells surrounded each pore, pore canal lining filaments composed at tetra/bisporangial conceptacle roof, and buried senescent tetra/bisporangial conceptacles completely infilled with relatively large and irregularly arranged calcified sterile cells (Foslie 1900; Baba 2000; Xia 2013). In this study, we observed that the morphology of our fresh materials collected from Korea correspond to those of the holotype of Lithothamnion japonicum. However, while the protuberances in holotype are subdichotomously to irregularly branched, protuberances in our materials collected from Korea are unbranched. Although many species have been delimited using apparent differences in the extent and nature of protuberance development, as evidenced (Woelkerling 1988), Adey (1966) provided conclusive evidence that protuberance development and form are highly variable within species and event within single plants and that this variability results from a variety of ecological conditions. Indeed, the development and form of protuberances have provided additional problems associated with species delimitation in Lithothamnion (Woelkerling 1988). Moreover, a number of studies have shown that considerable variation in growth-form can occur within a species (e.g. see Penrose and Woelkerling 1991; Woelkerling and Campbell 1992; Woelkerling and Harvey 1992). As the result, the differences of the shape of protuberances within L. japonicum did not seem to be significant enough to indicate separate species.

Gametangial conceptacles of Lithothamnion japonicum are very poorly known. When Foslie (1900) described L. japonicum, only tetra/bisporangial conceptacles were found. Masaki (1984) found both spermatangia and carpogonia within single conceptacles of L. japonicum . Baba (2000) illustrated with photographs of spermatangial conceptacles from $L$. japonicum. He recognized its characters in very simple way as follows: 1) conical shape of spermatangial conceptacles, 2) branched spermatangial filaments on the conceptacle chamber, and 3) senescent male conceptacles buried in to the thallus. In this study, we observed the detailed anatomical mor- 
phology about spermatangial conceptacles chambers. We suggest the followed additional diagnostic characters for the delimitation of species level of genus Lithothamnion: 1) shape of spermatangial conceptacles, 2) raised or sunken degree of spermatangial conceptacles, 3) shape of spermatangial conceptacles chamber, 4) shape of spermatangial conceptacle canal, 5) number of cells of spermatangial conceptacle roof, and 6) presence or absence of buried spermatangial conceptacles.

Although Lithothamnion japonicum has been reported from Japan and China (Okamura 1936; Yoshida et al. 1990; Yoshida 1998; Liu 2008; Zeng 2009; Xia 2013), in this study, we confirm extension of its distribution to the Northeast Asia including Korea.

\section{ACKNOWLEDGEMENTS}

This study was supported by a grant from the National Institute of Biological Resources (NIBR), funded by the Ministry of Environment (MOE) of the Republic of Korea (NIBR201801205). This research was also supported by Basic Science Research Program through the National Research Foundation of Korea (NRF) funded by the Ministry of Education, Science and Technology (2015R1D1A1A01 058359) and a grant from Marine Biotechnology Program (PJT200669 and 20170431) funded by Ministry of Oceans and Fisheries of Korean Government to Tae Oh Cho.

\section{REFERENCES}

Adey WH. 1966. The genera Lithothamnium, Leptophytum (nov. gen.) and Phymatolithon in the Gulf of Maine. Hydrobiologia 28:321-370.

Adey WH and PJ Adey. 1973. Studies on the biosystematics and ecology of the epilithic crustose Corallinaceae of the British Isles. Brit. Phycol. J. 8:343-407.

Aguirre J and JC Braga. 2005. The citation of nongeniculate fossil coralline red algal species in the twentieth century literature: an analysis with implications. Rev. Esp. Micropaleontol. 27:57-62.

Baba M. 2000. An identification guide of coralline red algae in Japan. Rep. Mar. Ecol. Res. Inst. 1:1-68.

Bassi D, JC Braga, E Zakrevskaya and EP Radionova. 2007. Redescription of the type collections of Maslov's speices of
Corallinales (Rhodophyta). II. Species included by Maslov in Archaeolithothamnium Rothpletz, 1891. Rev. Esp. Paleontol. 22:115-125.

Basso D and G Rodondi. 2006. A Mediterranean population of Spongites fruticulosus (Rhodophyta, Corallinales), the type species of Spongites, and the taxonomic status of S. stalactitica and S. racemose. Phycologia 45:403-416.

Chamberlain YM. 1990. The genus Leptophytum (Rhodophyta, Corallinales) in the British Isles with descriptions of Leptophytum bornetii, L. elatum sp. nov., and L. laevae. Brit. Phycol. J. 25:179-199.

Foslie M. 1900. New or critical calcareous algae. Det. Kgl. Nor. Vidensk. Selsk. Skr. 1899:1-34.

Foslie M. 1907. Algologiske notiser III. Det. Kgl. Nor. Vidensk. Selsk. Skr. 1906:1-34.

Guiry MD and GM Guiry. 2018. AlgaeBase. World-wide electronic publication, National University of Ireland, Galway. http://www.algaebase.org; Accessed on 20 March 2018.

Heydrich F. 1897. Melobesiae. Ber. Dtsch. Bot. 16:403-420.

Liu JY. 2008. Checklist of Biota of Chinese Seas. Science Press, Academia Sinica, Beijing.

Maneveldt G, YM Chamberlain and DW Keats. 2008. A catalogue with keys to the non-geniculate coralline algae (Corallinales, Rhodophyta) of South Africa. S. Afr. J. Bot. 74: 555-566.

Masaki T. 1984. Crustose coralline algae. Jap. J. Phycol. 32: 71-85.

Okamura K. 1936. Descriptions of Japanese Algae. Uchida Rokakuho, Tokyo.

Peña V, JJ Hernandez-Kantun, WH Adey and LL Gall. 2018. Assessment of coralline species diversity in the European coasts supported by sequencing of type material: the case study of Lithophyllum nitorum (Corallinales, Rhodophyta). Cryptogamie Algol. 39:1-15.

Penrose D and WJ Woelkerling. 1991. Pneophyllum fragile in southern Australia: implications for generic concepts in the Mastophoroideae (Corallinaceae, Rhodophyta). Phycologia 30:495-506.

Philippi RA. 1837. Beweis, dass die Nulliporen Pflanzen sind. Arch. Naturgesch. 3:387-393.

Tâmega FTS, R Riosmena-Rodriguez, R Mariath and MAO Figueiredo. 2014. Nongeniculate coralline red algae (Rhodophyta: Corallinales) in coral reefs from Northeastern Brazil and a description of Neogoniolithon atlanticum sp. nov. Phytotaxa 190:277-298.

Wilks KM and WJ Woelkerling. 1995. An account of southern Australian species of Lithothamnion (Corallinaceae, Rhodophyta). Aust. Syst. Bot. 8:549-583.

Woelkerling WJ. 1985. A taxonomic reassessment of Spongites 
(Corallinaceae, Rhodophyta) based on studies of Kützing's original collections. Brit. Phycol. J. 20:123-153.

Woelkerling WJ. 1988. The Coralline Red Algae: An Analysis of the Genera and Subfamilies of Nongeniculate Corallinaceae. British Museum (Natural History), London, and Oxford University Press, Oxford.

Woelkerling WJ and A Harvey. 1992. Mesophyllum incisum (Corallinaceae, Rhodophyta) in southern Australia: implications for generic and specific delimitation in the Melobesioideae. Brit. Phycol. J. 27:381-399.

Woelkerling WJ, G Gustavsen, HE Myklebost, T Prest $\varnothing$ and SM Såstad. 2005. The coralline red algal herbarium of Mikael Foslie: revised catalogue with analysis. Gunneria 77:1-627.

Woelkerling WJ, LM Irvine and AS Harvey. 1993. Growthforms in non-geniculate coralline red algae (Corallinales, Rhodophyta). Aust. Syst. Bot. 6:277-293.

Woelkerling WJ and SJ Campbell. 1992. An account of southern
Australian species of Lithophyllum (Corallinaceae, Rhodophyta). Bull. Br. Mus. Nat. His. Bot. 22:1-107.

Xia B. 2013. Flora Algarum Marinarum Sinicarum Tomus II Rhodophyta No. IV Corallinales. Science Press, Beijing.

Yoshida T. 1998. Marine Algae of Japan. Uchida Rokakuho Publishing Co., Ltd., Tokyo.

Yoshida T, M Suzuki and K Yoshinaga. 2015. Checklist of marine algae of Japan. Jap. J. Phycol. 63:129-189.

Yoshida T, Y Nakajima and Y Nakata. 1990. Check-list of marine algae of Japan. Jap. J. Phycol. 38:269-320.

Zeng C. 2009. Seaweeds in Yellow Sea and Bohai Sea of China. Science Press, Beijing.

Received: 21 August 2018 Revised: 3 September 2018 Revision accepted: 4 September 2018 